\section{E-LOGOS}

ELECTRONIC JOURNAL FOR PHILOSOPHY ISSN 1211-0442

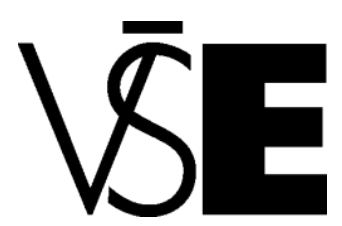

University of Economics

Prague

\title{
Věda v 21. století: dynamický kognitivní systém
}

\author{
Martina Chalupská
}

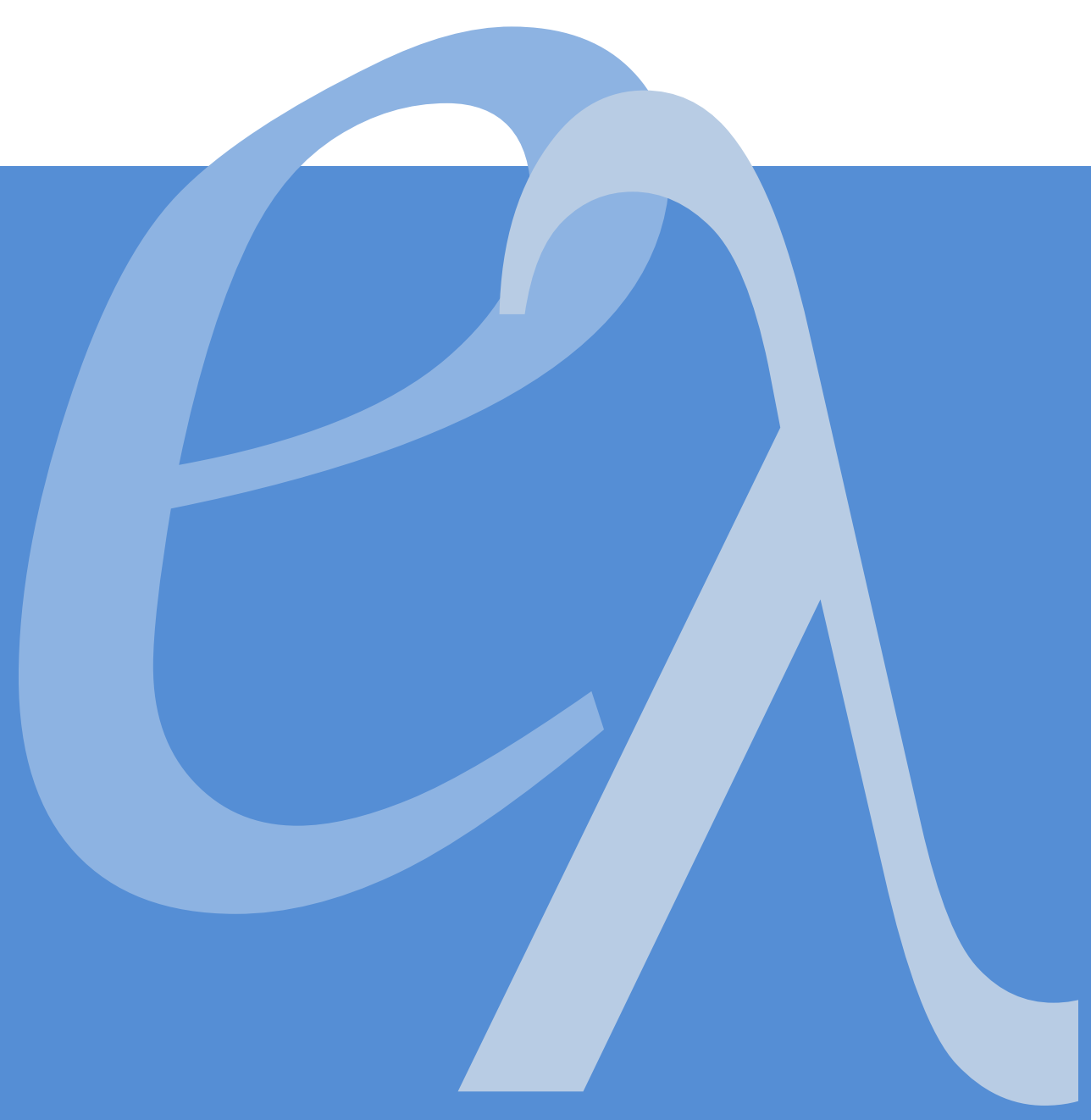




\begin{abstract}
The article deals with the transformation of approaches to the formation of scientific knowledge. The traditional epistemology of science based on the method of induction or deduction represents an abstract formally-logical structured and atemporal construct. In the light of the comprehensively-systemic approach this construct is opposed to the attempt to envisage science as a dynamic cognitive system. The comprehensively-systemic approach is defended in the article because it is able to embrace the indisputable social and historical dimension of science while recognizing the psychological abilities of individuals or more precisely groups. Scholarly teamwork is absolutely necessary in terms of the increasing complexity of science which is not captured by the normal static formal models.
\end{abstract}

Keywords: science, dynamic cognitive system, complexity, relation, co-citation, fractal.

\begin{abstract}
Abstrakt
Studie se zabývá proměnou přístupu k vytváření vědeckých poznatků. Tradiční epistemologie vědy založená na metodě indukce či dedukce představuje abstraktní formálně-logicky strukturovaný a atemporální konstrukt. Ve světle komplexněsystémového přístupu se však tento konstrukt jeví jako nepřátelský vůči snaze pojímat vědu jako dynamický kognitivní systém. Ve studii je hájen právě komplexněsystémový př́istup, nebot' je schopen obsáhnout nezpochybnitelný sociální a historický rozměr vědy a stejně tak psychologické schopnosti jednotlivců, respektive skupin. Týmová spolupráce je z hlediska stále se zvyšující komplexity vědy zcela nezbytná a běžné statické formální modely vědy nejsou schopny ty to její aspekty reflektovat.
\end{abstract}

Klíčová slova: věda, dynamický kognitivní systém, komplexita, relace, kocitace, fraktál.

Studie byla financována v rámci projektu Inovativní filosofické koncepce na pomezí metafyziky a vědy, SGS-2014-067. 


\section{Principy komplexně-systémového přístupu $k$ vědě}

Po více než tři století se vědecké paradigma a filosofie vědy vyjadřovaly v termínech determinismu, linearity, jednoduchých kauzálních zákonů a analýzy na vzájemně izolované fundamentální částice. Tento ortodoxní vědecký rámec však v prvních třech desetiletích 20. století čelil výzvám relativistické a především kvantové fyziky. $\mathrm{V}$ šedesátých letech 20. století, kdy se vědci učili novému pojmu "chaosu“, nemohla být již nadále ignorována nelinearita, kterou objevil J. H. Poincaré. ${ }^{1}$ Osmdesátá léta 20. století dovedla vědu ke komplexitě.

Komplexně systémové principy, metody a modely byly $\mathrm{v}$ oblasti vědy explicitně uznány až v nedávné době. Jejich aplikace na nejrůznější oblasti lidského života jsou stále více aktuální v posledních dvaceti pěti letech. Zájem o jejich výzkum představuje reflexi hluboké komplexity všech aktuálních vědeckých procesů. ${ }^{2}$

Základní charakteristiky komplexních systémů jsou aplikovatelné v novém pohledu na vědu jako takovou, ${ }^{3}$ přičemž souvisí s jedním ze základních atributů lidského života - s vědomím. Ǩídí se myšlenkou: „Dívejme se na vědu jako na dynamický kognitivní systém“.

Tento přístup je však zcela odlišný od tradičních modelů vědy, které se utvářely a dominovaly ve dvacátých až sedmdesátých letech minulého století. Jsou zde myšleny tradiční epistemologické koncepce opírající se o logiku a představující abstraktní formálně-logicky strukturovaný atemporální konstrukt. Empiricismus používal jako vstupní informace empirická data a matematické zákony a prostřednictvím induktivní logiky dospěl k nejlepší možné teorii a specifikaci experimentu, jenž danou teorii potvrzoval. Pro falsifikacionismus byly vstupními informacemi hypotézy, empirická data a matematické zákony a cestou deduktivní logiky se mělo dospět k teoriím, které by byly pomocí testů priijaty nebo odmítnuty.

Rozhodování jednotlivých vědců by tak mělo být modelováno univerzálním abstraktním formálním konstruktem. Jedná se o komputační proces logických

\footnotetext{
${ }^{1}$ Poincarého pojednání o tzv. problému tří těles, později rozpracované do tř́ísvazkového díla Les Méthodes Nouvelles de la Mécanique Céleste, publikované ve třináctém svazku Acta Mathematica v roce 1890, poprvé uvedlo př́klad chaotického chování deterministického systému. (Viz Diacu, F. The Solution of the $n$-body Problem, The Mathematical Intelligencer, 18(3), 1996, s. 67.)

${ }^{2}$ Srov. Hooker, C. A., ed. Handbook of The Philosophy of Science. Philosophy of Complex Systems. Amsterdam; London: North Holand (Elsevier), 2011.

${ }^{3}$ „Nelinearita; neaditivnost; ireversibilita, restrikce - holonomické a neholonomické; equilibrium a stabilita statické a dynamické; amplifikace; citlivost na počáteční podmínky; finitní deterministická nepredikovatelnost; porušení symetrie; bifurkace; sebe-organizace; emergence; restrikce - aktivující a koordinované; vnitřní celková soudržnost; řád; organizace; modularita; hierarchie; cesta závislosti a historicita; omezení duality, tvorba supersystému; koordinovaná časová a prostorová diferenciace s funkční organizací; mnohaměřítková a multiřádová funkční organizace; autonomie; adaptace; adaptivnost; učení; modelová specifičnost/modelová pluralita; model jako ústřední pojem; vzájemná závislost zákonů.“(Viz Hooker, C. A. Introduction to Philosophy of Complex Systems: A. In: Handbook of the Philosophy of Science. Philosophy of Complex Systems, s. 20-21.) Důsledkem skutečnosti, že dnes nejsme schopni systematicky propojit všechny charakteristické vlastnosti komplexních systémů, je fakt, že neexistuje jednotná věda o komplexitě, ale spíše mnoho věd o komplexitě.
} 
sekvencí, avšak $\mathrm{v}$ atemporálním slova smyslu, nikoli proces dynamický. Tato dominantní tradice se tak jeví jako neprátelská $\mathrm{k}$ pojímání vědy jako dynamického kognitivního systému. Žádný věčný formální inferenční vzorec nedokáže podchytit transformativní dynamiku vědy, která je vytvářená lidskou kreativitou. Poznání implicitně obsahuje dynamickou povahu procesů, ve kterých probíhá. ${ }^{4}$

V druhé polovině 20. století přichází ze stran filosofư i historiků vědy snaha o komplexnější vědní analýzu, která vede rovněž $\mathrm{k}$ reflexi faktorů, které jsou vněǰš́ vzhledem ke struktuře vědeckých poznatků. Jestliže chceme skutečně pochopit vývoj vědy, jsou její pouhá vnitřní logická pravidla nepostačující, nebot' nejsou schopna vysvětlit její dynamiku. ${ }^{5}$ Toto úsilí s sebou přináší odklon od noeticko-logického zkoumání vycházejícího zejména z pozitivizmu k společensko-historickému ukotvení vědy, které je spojeno s objevy relativistické a kvantové fyziky. Logický pozitivizmus šel cestou dehumanizace vědy a její vývoj se tak odehrává pouze na pozadí jejích vnitřních aspektů, je dán logickou posloupností aktuálních otázek. Je zde snaha o nalezení demarkačního kritéria mezi vědou a nevědou.

Na druhou stranu společensko-historický způsob zkoumání vědy nepřijímá kumulativní model jejího vývoje a do centra pozornosti se dostává pojem diskontinuity a jsou zohledňovány vnější faktory ovlivňující vývoj vědy (vědní politika, světové názory jednotlivých vědců apod.).

\section{Současná povaha vědy}

Odmítnutím verifikacionismu i falsifikacionismu předkládá novou interpretaci vývoje vědy T. S. Kuhn, podle něhož $\mathrm{k}$ rozšiřování vědeckého poznání dochází prostřednictvím dynamického vývoje vědy, nikoli reflexí logické struktury výsledků vědeckého výzkumu. ${ }^{6}$

C. A. Hooker a W. E. Herfel navazují na Kuhnův re-organizační model vědy s konstantními, řád vnášejícími pravidly (normální věda), která jsou přerušena ostrými, sebe-organizačními a rozkladnými fázovými přechody (revoluce), ve kterých se dosavadní pravidla anulují a re-konstituují sama sebe v odlišné vzorce či struktury. Tento model považují za analogický $\mathrm{k}$ dynamickému popisu vědy. ${ }^{7}$ Nicméně podle Hookera a Herfela je Kuhnův model př́liš hrubý, nebot' historické změny probíhající

\footnotetext{
${ }^{4}$ Hooker, C. A. Introduction to Philosophy of Complex Systems: A. In: Handbook of the Philosophy of Science. Philosophy of Complex Systems, s. 54-55.

${ }^{5}$ Fajkus, B. Filosofie a metodologie vědy. Vývoj, současnost a perspektivy. Praha: Academia, 2005, s. 118.

${ }^{6}$ Kuhn, T. S. Logic of Discovery or Psychology of Research? In: Lakatos, I. - Musgrave, A. (eds.) Criticism and the Growth of Knowledge. London: Cambridge University Press, 1970, s. 1-2.

${ }^{7}$ Herfel, W. E. - Hooker, C. A. From Formal Machine to Social Colony: Toward a Complex Dynamical Philosophy of Science. In: Dalla Chiara, M. L. - Giuntini, R. - Laudisa, F. (eds.) Language, Quantum, Music: Select Proceedings of the 10th International Congress of Logic, Methodology and Philosophy of Science. Boston: Kluwer, 1999, s. 7
} 
uvnitř vědy jsou mnohem složitější a také rozmanitější. ${ }^{8}$ „Když Kuhn slavně prohlásil, že vědecké revoluce nemohou být chápány jako formální strojové procesy, nebylo toto tvrzení přijato jako nový druh sociálně-vzdělávacího procesu, ale místo toho bylo zcela zavrženo jako „iracionální" a zcela mimo studium vědecké epistemologie.“"

Podle Kuhna je přechod od jednoho paradigmatu k druhému přechodem „,...mezi nesouměřitelným, nemůže se uskutečnit krok za krokem za podpory logiky a neutrální zkušenosti. Stejně jako změna Gestalt musí také tento přechod nastat bud' naráz (avšak nikoli nutně $\mathrm{v}$ jediném okamžiku), nebo nenastane vůbec." $10 \mathrm{~A}$ v důsledku toho "diskuse o volbě teorie nelze rozvíjet ve formách, které by se plně podobaly logickému nebo matematickému důkazu. ${ }^{11}$

Odmítnutím využívání jistých pravidel racionality při přijímání nebo opouštění vědeckých teorií bývá svými kritiky ${ }^{12}$ Kuhn označován za iracionalistu. Proti tomuto nařčení se brání ve stati „Reflections on my Critics“.

Podle Kuhna jsou důvody pro volbu dané teorie důvody klasicky uznávané ve filosofii vědy: přesnost, rozsah, jednoduchost, př́nosnost. A tyto důvody Kuhn chápe jako hodnoty a ty mohou být různými odborníky interpretovány odlišně. $V$ př́padě volby teorie se tedy rozhodujeme na základě hodnot, nikoli na základě pravidel. $Z$ tohoto důvodu vědci ve stejných situacích činí různá rozhodnutí. Variabilita jednotlivých rozhodnutí je esenciální pro vědecký pokrok. ${ }^{13}$ „Při výběru teorie neexistuje žádný neutrální postup, neexistuje systematická rozhodovací procedura, která by při správném použití musela nutně dovést každého jedince a každou skupinu k témuž rozhodnutí." 14

Kuhn tedy představuje jistý přelomový článek mezi tradiční formálně-logickou koncepcí rozumu a komplexně-dynamickými principy aplikovanými jednak na interakce jednotlivých vědců a jednak na vědu jako takovou.

Hooker a Herfel tedy svůj dynamický př́istup opírají o Kuhnův pojem „vědecké revoluce“, který považují za synonymum k tzv. bifurkacím. ${ }^{15}$ Bifurkace bychom mohli s J. D. Barrowem definovat jako bod větvení do kvalitativně nových typů chování ve

\footnotetext{
${ }^{8}$ Ibid.

${ }^{9}$ Hooker, C. A. Introduction to Philosophy of Complex Systems: A. In: Hooker, C. A. (ed.) Handbook of the Philosophy of Science. Philosophy of Complex Systems, s. 55.

${ }^{10}$ Kuhn, T. S. Struktura vědeckých revolucí. Praha: OIKOYMENH, 1997, s. 150.

${ }^{11}$ Ibid., s. 196.

${ }^{12}$ Např. Israel Scheffler, kritizujíce Kuhna, dochází k závěru, že „...přijetí nové vědecké teorie je intuitivní až mystickou záležitostí, otázka primárně psychologické deskripce a nikoli logické a metodologické kodifikace. (Viz Scheffler, I. Science and Subjectivity. Indianapolis: Hackett Pub. Co., 1982, s. 18.)

${ }^{13}$ Kuhn, T. S. Reflections on my Critics. In: Lakatos, I. - Musgrave, A. (eds.) Criticism and the Growth of Knowledge. London: Cambridge University Press, 1970, s. 261-262.

${ }^{14}$ Kuhn, T. S. Struktura vědeckých revolucí, s. 196-197.

${ }^{15}$ Pojem „bifurkace“ zavedl Henri Poincaré v roce 1885 ve svém článku L'Équilibre d'une masse fluide animée d'un mouvement de rotation. (Viz Poincaré, J. H. L'Équilibre d'une masse fluide animée d'un mouvement de rotation. Acta Mathematica, 7(1), 1885, s. 259-380.)
} 
smyslu náhlé spíše než postupné změny. Konkrétně jde o přechod nelineárního systému do oblasti, kde nové zákony determinují další chování systému. ${ }^{16}$

Tyto přechody se označují také jako tzv. porušení symetrie. Systém se sebeorganizuje - z neuspořádaného stavu, kdy systém kolísá mezi dvěma hodnotami je vybrána jedna cesta, a jsou získány nové kvality. Při aplikaci těchto principů vlastních všem nelineárním dynamickým systémům na vědu jako takovou zjistíme, že v období hlubokých a rozsáhlých změn, tedy v období vědeckých revolucí/bifurkací získává novou dynamiku, nové vlastnosti, mění se vědecké experimenty, metody, teorie. Tyto změny mají silný vliv na dynamiku vývoje vědy a je potřeba je odlišovat od ostatních komplexních změn menšího rozsahu probíhajících ve vědě neustále. ${ }^{17}$

V souvislosti s porušováním symetrie se americký fyzik P. W. Anderson snaží ve svém slavném článku „More Is Different“ ukázat limity redukcionistického přístupu ve vědě. Podle Andersona komplexní systémy fungují na základě fundamentálních zákonů operujících na úrovních základních komponentů těchto systémů. Při této redukci se ovšem ztrácejí fenomény, komplexnosti nejvyšších úrovní. Dochází zde k jistému druhu porušování symetrie: z komplexního systému jsme schopni odvodit fundamentální zákony, ale při opačném, induktivním postupu můžeme dospět k mnoha variantám našeho původního celku, avšak bez jeho apriorní znalosti to nemusí být ten, ze kterého jsme vycházeli. ${ }^{18}$ Důvodem této skutečnosti jsou emergentní jevy, jejichž existenci naznačil poprvé již Aristoteles v Metafyzice svým výrokem „Celek je víc než souhrn jeho částí“19.

Redukcionismus jako takový je pro vědu navýsost užitečný nástroj, nebot' lidská mysl není schopná chápat svět $\mathrm{v}$ jeho celistvosti. Je ovšem nezbytné uvědomovat si jeho limity. Př́iznačně to ve své knize vyjádřili environmentalista P. Richerson a antropolog R. Boyd: „Redukcionismus evoluční vědy je ryze taktický. Děláme, co umíme, tváří v tvář děsivé rozmanitosti a složitosti“" ${ }^{20}$

Aby tato složitost a rozmanitost, tedy komplexita, vůbec mohla vzniknout, jsou nezbytné dvě složky: nevratnost a nelinearita. Nevratnost představuje tok času z minulosti do budoucnosti. Je zde jednoznačný odklon od klasické fyziky s jejím pojetím základních procesů jako deterministických a vratných, která náhodnost a nevratnost vnímá jako pouhou (avšak nevysvětlitelnou) výjimku. Nelinearita, oproti

\footnotetext{
${ }^{16}$ Barrow, J. D. The World Within the World. Oxford: Clarendon Press, 1988, s. 302.

17 Herfel, W. E. - Hooker, C. A. From Formal Machine to Social Colony: Toward a Complex Dynamical Philosophy of Science, s. 12.

${ }^{18}$ Anderson, P. W. More Is Different. Broken Symmetry and the Nature of the Hierarchical Structure of Science. Science, 177(4047), 1972, s. 393-396.

${ }^{19}$ Aristoteles. Metafyzika. Praha: Nakl. Jana Laichtera, I946, 10f-1045a.

${ }^{20}$ Richerson, P. J. - Boyd, R. Not by Genes Alone. How Culture Transformed Human Evolution. Chicago: UP, 2005, s. 98.
} 
linearitě dominující ve vědě po více než tři staletí, vede ke komplexnímu a často také neočekávanému chování. ${ }^{21}$

Věda jako taková představuje systém, ve kterém spolu jednotliví vědci interagují v nelineárních vztazích (vyměňují si informace), jsou nuceni respektovat určité institucionální restrikce (laboratorní procedury, publikování v odborných časopisech) a jsou podporováni neustálým tokem materiálních i nemateriálních prostředků, čímž je věda udržována ve stavu dynamické rovnováhy. ${ }^{22}$

Dřivější analytický přístup k modelování vědy se snažil tyto interakce redukovat na několik málo logických pravidel. Tento přístup je neadekvátní $\mathrm{k}$ dynamickému charakteru vědy, v níž se interakční pravidla mění v jednotlivých kontextech. ${ }^{23}$

Logický pozitivizmus opomíná skutečnost, že jsou to lidé, nikoli formálně-logická pravidla, kteří utvářejí vědu. Věda je součástí kultury a proto je nutné při studiu vědeckého poznání uplatňovat přístup zahrnující psychologické, sociální a historické faktory a vědu chápat jako nelineární dynamický systém.

\section{Relace a kocitace jako základ komplexně-dynamické povahy vědy}

Věda 21. století je ve svém základu relačním procesem, ve kterém je vědecké poznání produkováno, resp. koprodukováno prostřednictvím vztahů mezi jednotlivými vědci nebo mezi vědci a veřejnými zájmovými stranami. Současný trend vytváření vědeckého poznání v týmové spolupráci, přinášející do struktury vědeckého poznání sociální a kulturní normy, zaručuje komplexnější a tedy hodnotnější vědecké výsledky. ${ }^{24}$

Stefan Wuchty dokázal, že výsledky týmových výzkumů mají jednak větší vliv ve vědecké komunitě a také větší citační index. Posun směrem k týmové spolupráci, nastal v oblasti přírodních, sociálních a humanitních věd, inženýrství a umění přibližně od šedesátých let 20. století jako reakce na vzrůstající komplexitu vědeckých poznatků. ${ }^{25}$

Tato tendence souvisí také s proměnou struktury a dynamiky vědecké evoluce. Vědečtí výzkumníci a vědecké články se navzájem podporují. Vědci prostřednictvím

\footnotetext{
${ }^{21}$ Coveney P. - Highfield, R. Mezi chaosem a řádem. Hranice komplexity: hledání řádu v chaotickém světě. Praha: Mladá fronta, 2003, s. 23-24.

${ }^{22}$ Herfel, W. E. - Hooker, C. A. From Formal Machine to Social Colony: Toward a Complex Dynamical Philosophy of Science, s. 11.

${ }^{23}$ Ibid.

${ }^{24}$ Tebes, J. K. - Thai, N. D. - Matlin, S. L. Twenty-First Century Science as a Relational Process: From Eureka! To Team Science and a Place for Community Psychology. American Journal of Community Psychology, 53(3-4), 2014, s. 475.

${ }^{25}$ Wuchty, S. - Jones, B. F. - Uzzi, B. The Increasing Dominance of Teams in Production of Knowledge. Science, 316(5827), 2007, s. 1037.
} 
referencí propojují články v kocitační sítě a články spojují vědce ve koautorských sítích. ${ }^{26}$

Tento model představuje mechanismus „bohatý se stává bohatším“27 (rich-getricher) vlastní citačním sítím článku (paper citation networks). Vzniká v důsledku sítové aktivity jednotlivých autorů čtoucích a citujících články a také referencí uvedených v těchto článcích. ${ }^{28}$

Zakladatel scientometrie de Sola Price publikoval v roce 1965 článek s názvem „Networks of Scientific Papers“, ve kterém popsal model citačních referencí mající zásadní dopad na povahu vědeckého výzkumu. Tento model spočíval v analýze distribuce bibliografických referencí ve vědeckých článcích z roku 1961, přičemž reflektované reference byly vymezeny lety 1862 - 1961. ${ }^{29}$ Price dospěl k závěru, že čím je literatura starší, tím má méně referencí v literatuře novější. Za frekvenčně nižší citovanost starší literatury je podle Price zodpovědný tzv. faktor bezprostřednosti (immediacy factor), tedy frekvence citace současné literatury vzhledem $\mathrm{k}$ frekvenci citace literatury dřívější. ${ }^{30}$ Kvantitativním studiem tohoto faktoru lze následně porovnat způsoby komunikace charakteristické pro jednotlivé disciplíny a doplnit tak data $z$ jiných zdrojů. ${ }^{31}$

Anthony F. J. van Raan zopakoval Priceho analýzu ovšem na vyšším prostorovém měřítku. Odhlédl od individuálních disciplín a zaměřil se na globální dynamiku. S výjimkou meziválečného a poválečného období potvrdil Priceho závěr: vývoj vědy odpovídá extra-exponenciální distribuci vědy. Z Priceho studie vyvodil dva hlavní závěry. Za prvé, $\mathrm{v}$ průběhu času dochází $\mathrm{k}$ exponenciálnímu nárůstu citovanosti novějších článků. Za druhé, během I. a II. světové války zaznamenal počet referencí značný pokles, který následovala fáze vzestupu k úrovni, jež byla více či méně extrapolována z období před válkami. Van Raan tuto závislost počtu citovaných dokumentů na daném „citačním“ roce, nazývá výskytem podle stáří (age distribution). Jedná se o závislost na růstu vědy (growth) a zastarávání dříve publikovaných vědeckých článků (ageing).

\footnotetext{
${ }^{26}$ Börner, K. - Maru, J. T. - Goldstone, R. L. The Simultaneous Evolution of Author and Paper Networks. PNAS, 101(1), 2004, s. 5266.

${ }^{27}$ Tento jev také známý jako Matthew effect (Srov. Merton, R. K. The Sociology of Science. Chicago: University of Chicago Press, 1973.), cumulative advantage (Price, D. J. de Solla. A General Theory of Bibliometric and Other Cumulative Advantage Processes. Journal of The American Society for Information Science, 27(5), s. 292-306.) nebo preferential attachment (Barabási, A.-L. - Albert, R. Emergence of Scaling in Random Networks. Science, 286(5439), 1999, s. 509-512.)

${ }^{28}$ Börner, K. - Maru, J. T. - Goldstone, R. L. The Simultaneous Evolution of Author and Paper Networks. PNAS, 101(1), 2004, s. 5266.

${ }^{29}$ Price, D. J. de Solla. Networks of Scientific Papers. Science, 149(3683), 1965, s. 513.

${ }^{30}$ Ibid.

31 MacRae, D, JR. Growth and Decay Curves in Scientific Citations. American Sociological Review, 34(5), 1969 , s. 631.
} 
K samotné závislosti počtu referovaných dokumentů na stáří vědy se přidává závislost na čase (time-dependent distribution). Ta vyjadřuje skutečnost, že dřive bylo publikováno mnohem méně vědecké literatury, než je tomu dnes. Počet citovaných dokumentů je tedy závislý na růstu a tedy stárnutí vědy a také na celkové produkci vědeckých prací. ${ }^{32}$

Van Raan dále vyvíjí model růstu a diferenciace vědy ve třech následujících krocích.

Nejprve vychází z předpokladu, že žádný reálný systém nevykazuje absolutní vzájemnou konektivitu všech svých jednotlivých částí. Ty interagují pouze na lokální úrovni a v důsledku systém vykazuje konektivitu pouze parciální. Věda, představující komplexní systém, je tvořena interagujícími subsystémy (vědní disciplíny apod.) s vlastním exponenciálním růstem.

Druhý předpoklad se týká „biologické“ nikoliv pouze disturbanční povahy "stárnutí“ vědy. Tím je zde míněn vznik a následný „věk“ vědeckých objevů, které velmi často znamenají také vznik nového vědního oboru, tedy nového subsystému. Jádro předpokladu spočívá v myšlence, že nově vnikající subsystémy jsou „kolébkou“ pro zárodečný vývoj nových objevů, k nimž dojde s pravděpodobností proporcionální $\mathrm{k}$ velikosti daného subsystému. Tyto objevy dají vznik opět novým subsystémům atd. Van Raan chápe vědu ve smyslu „....koherentního systému publikací vyvíjejícího se $\mathrm{v}$ čase jako živé organismy a majícího původ $\mathrm{v}$ jednom $\mathrm{z}$ mnoha exponenciálně rostoucích subsystémů,..."33

Ve třetím bodu se dostáváme $\mathrm{k}$ distribuci všech subsystémů, založené na jejich velikosti (počtu publikací), v rámci systému jako celku. Tento poslední krok může být odvozen z výše popsané časové závislosti růstu a "stárnutí“ vědy.

V důsledku je tedy věda sebe-organizační kognitivní ekosystém, jehož fraktální povaha umožňuje změřit míru rozmanitosti tohoto kognitivního systému, tedy distribuci jednotlivých „druhů vědců“ mezi větší a menší vědní disciplíny, subdisciplíny apod.

Podle van Raana je dále nemožné v termínech dynamického kognitivního systému považovat větší vědecké objevy za esenciálně odlišné od menších vědeckých objevů. To má zásadní filosofické implikace v podobě rozporu s Kuhnovou teorií vědeckých revolucí. ${ }^{34}$ „Není zde žádná fáze „normální“ vědy, jenž je alternativní k velmi dobře definovaným periodám „revoluční“ vědy, ve které nová paradigmata začínají diktovat nová pravidla. Věda je vždy revoluční, ale typicky statistickým komplexem systémů, které jsou většinou menší a pouze vzácně představují zásadní průlomy. “35

\footnotetext{
32 van Raan, A. F. J. On Growth, Ageing and Fractal Diferentiation of Science. Scientometrics, 47(2), 2000, s. 347-348.

${ }^{33}$ Ibid., s. 355.

${ }^{34}$ Ibid. S. 360.

${ }^{35}$ van Raan, A. F. J. On Growth, Ageing and Fractal Diferentiation of Science. Scientometrics, 47(2), 2000 , s. 360.
} 
Vidíme zde tedy zásadní rozpor mezi Kuhnovou teorií, ve které jsou nová pravidla nastavena po předešlých revolučních změnách a koncepcí van Raana, která považuje vědecké objevy, bez ohledu na jejich dopad, za pravidla sama o sobě.

Nové myšlenky či oblasti výzkumu mohou být sice považovány za revoluční, ovšem na odlišných úrovních důležitosti či významnosti. Ve skutečnosti se většinou vyvíjejí lineárně ve vzájemné návaznosti. Kvantitativní analýzy si nekladou nároky na lepší vysvětlení změn probíhajících ve vědě. Filosofům a sociologům nabízejí alternativní perspektivu, která se nesnaží odstranit analýzy kvalitativní. ${ }^{36}$ Jde jí pouze $\mathrm{o}$ „....plné rozprostření metody a kritické prozkoumání všech přínosů, které se mohou takto objevit." 37

Již bylo naznačeno, že týmová vědecká spolupráce úzce souvisí se vzájemnou citací jednotlivých článků. Kocitační analýza ${ }^{38}$ byla zavedena v roce 1973, a to dvěma autory současně nicméně nezávisle na sobě. Henry Small ve svém článku "Co-citation In the Scientific Literature: a New Measure of the Relationship Between Two Documents" definuje kocitaci jako „...frekvenci, se kterou jsou dva dříve vydané dokumenty společně citovány v literatuře publikované později.“" 39 Irena Marshakova-Shaikevich v článku nazvaném "System of Document Connections Based on References" pohlíží na analýzu bibliografických referencí jako na „...stávající nástroj studia informačních procesů ve vědě, možnou klasifikaci dokumentů." ${ }^{40} \mathrm{Z}$ údajů na Web of Science je zřejmé, že Smallova práce byla ovšem citována častěji, a to patrně z toho důvodu, že práce Marshakova-Shaikevich byla publikována v ruštině. ${ }^{41}$

Spolu s van Raanem můžeme pojem kocitace popsat následovně: Dva dřive publikované články nazveme jako kocitované (co-cited), jestliže jsou oba současně citované článkem pozdějším a dále jeden $z$ této dvojice může tvořit pár s článkem třetím. Takto vzniká svazek kocitvaných článků a následně i mapa citačního pole. ${ }^{42}$ Obecně je možné říci, že nejnižší úrovně citační mapy, představují menší výzkumné záměry, zatímco na úrovních vyšších nacházíme mnoho oborů, podoborů a disciplín. Van Raan růst vědeckého poznání přirovnává k vývoji přírodních fenoménů, tedy ke

\footnotetext{
${ }^{36}$ Bellis, Nicola de. Bibliometrics and Citation Analysis: From the Science Citation Index to Cybernetics. Plymouth: The Scarecrow Press, Inc., 2009, s. 112-113.

${ }^{37}$ Price, D. J. de Solla. Science Since Babylon. New Haven: Yale University Press, 1975, s. 163.

${ }^{38}$ Kocitace se někdy také nazývají paralelní citace a jejich definice je následující: „Bibliographic Co-Citation is a popular similarity measure used to establish a subject similarity between two items. If A and B are both cited by $\mathrm{C}$, they may be said to be related to one another, even though they don't directly reference each other. If A and B are both cited by many other items, they have a stronger relationship. The more items they are cited by, the stronger their relationship is." (Martins, B. Class CoCitation [online], [cit. 7. 6. 2014]. Dostupné z: http://webla.sourceforge.net/javadocs/pt/tumba/links/CoCitation.html]).

39 Small, H. Co-citation in The Scientific Literature: a New Measure of The Relationship Between Two Documents. Journal of the American Society for Information Science, 24(4), 1973, 265.

${ }^{40}$ Marshakova-Shaikevich, I. System of Document Connections Based on References". Nauchn-Techn.Inform., 6(2), 1973, s. 3.

${ }^{41}$ Srov. Havemann, F. Einführung in die Bibliometrie. Berlin: Gesellschaft für Wissenschaftsforschung, 2009, s. 33.

42 van Raan, A. F. J. Fractal Dimension of Co-citations. Nature, 347(626), 1990, s. 626.
} 
svazkové struktuře. $Z$ pohledu prostorového měřítka se totiž jednotlivé vědecké objevy shlukují (cluster) okolo významných vědeckých institucí. $Z$ pohledu časového měřítka se tyto objevy ukazují jako průlomové události, od nichž se směřuje další vědecký pokrok. Van Raan tedy zkoumá nefyzikální abstraktní strukturu vědy, v rámci níž se lidské poznání seskupuje podle specifických agregačních pravidel. Nezbytnou součástí vědy je citační aktivita jednotlivých vědců. Vzniklou citační mapu analyzuje podle geometrických vlastností a velikostního rozložení kocitačních svazků vyjadřuje v termínech fraktální dimenze. ${ }^{43}$

Van Raan navazuje na Benoita Mandelbrota, který dokázal, že většina přírodních struktur je př́liš složitá, nepravidelná, rozkouskovaná, nebo amorfní na to, aby se dala popsat jazykem matematiky. ${ }^{44}$ Euklidova geometrie byla spojována s abstraktní dokonalostí, která se $\mathrm{v}$ reálném světě v podstatě nevyskytuje. Mandelbrot nalezl způsob jak matematicky popsat tvary př́rodních útvarů. To umožňuje různě členité útvary alespoň přibližně měřit. Je to hledání zákonitosti tam, kde zdánlivě žádné nejsou. Jeho práce se tak stala základem teorie chaosu - matematiky nelineárních dynamických systémů.

Van Raan jako první popsal v roce 1990 vědu v termínech kognitivního ekosystému s výzkumnými komunitami v podobě jistých "druhů vědců“ (species of scientists) jejichž citační aktivitou vzniká infomační prostor. Ten má fraktální povahu, která je odrazem dynamického procesu, při němž z již etablovaných vědeckých oborů emergují nové oblastí výzkumného zájmu. Je zde tedy zřejmá vazba na povahu př́rodních ekosystémů jako takových. Systémovou ekologií se zabývá francouzský vědec Serge Frontier, který život chápe jako interakční sít' s nepřetržitými toky látky, energie a informací skrze vzájemné vztahy. Geometrické vyjádření vztahu mezi dvěma přilehlými interagujícími částicemi je podle Frontiera př́liš spletité a nabývá podoby spíše vzájemně se prostupujícího objemu namísto hladkého povrchu. Ve skutečnosti to ale nejsou ani povrchy ani objemy, ale fraktály.“ 45

Van Raan tyto procesy probíhající $\mathrm{v}$ ekologických systémech převádí na procesy probíhající ve vědě. Jestliže kocitační svazky reprezentují zaměření jednotlivých vědců (species of scientists), které odpovídá toku látky a informace, potom fraktální svazková distribuce vyjadřuje míru rozmanitosti vědecké komunity. Struktura svazků na nižších úrovních je tvořena parametry (tok lidí, peněz a informací) $s$ více "náhodnou“ povahou než na úrovních vyšších. Zde již obsažená dynamika následuje vzory, které sdílejí fraktální distribuci. Fraktální geometrie úzce souvisí s řádem

\footnotetext{
${ }^{43}$ van Raan, A. F. J. Fractal Dimension of Co-citations. Nature, 347(626), 1990, s. 626.

${ }^{44}$ Srov. Mandelbrot, B. How Long Is the Coast of Britain? Statistical Self-Similarity and Fractional Dimension. Science, 156(3775), 1967. Zde matematicky zdůvodňuje, jak se délka pobřeží zvětšuje s podrobností měřítka, v jakém ji pozorujeme.

${ }^{45}$ Frontier, S. Applications of Fractal Theory to Ecology. In: Legendre, P. - Legendre, S. (eds.) Developments In Numerical Ecology. Springer Verlag: Berlin, 1987, s. 335.
} 
v nerovnovážných systémech, a proto je studium fraktální povahy kocitačního seskupování významným bodem v dalším modelování vědeckých ekosystémů. ${ }^{46}$

Citační modely nám tedy umožňují zjištovat význam určité literatury v různých oblastech vědy. V souvislosti s výše popsaným zastaráváním literatury a tedy klesající frekvencí citování starší literatury je možné vysledovat ty dokumenty, které se stále i přes své stáří odkazují a tím získat jakési „tvrdé jádro“ vědy.

\section{Závěr}

Ve svém článku jsem se snažila poukázat na systémové principy, metody a modely jakožto na kompetentní nástroj pro analýzu vývoje a struktury vědeckého poznání přičemž tyto nástroje byly postaveny do konfrontace s tradičními epistemologickými koncepcemi opírajícími se o logiku a představujícími abstraktní formálně-logicky strukturovaný atemporální konstrukt. Snaha přiklonit se ke komplexnější vědní analýze se objevila $\mathrm{v}$ druhé polovině 20 . století a vede především $\mathrm{k}$ reflexi faktorů, které jsou vnější vzhledem ke struktuře vědeckých poznatků.

Jistý přelomový článek mezi tradiční formálně-logickou koncepcí rozumu a komplexně-dynamickými principy představuje T. S. Kuhn se svým konceptem vědeckých revolucí. Na toto pojetí navazuje C. A. Hooker a W. E. Herfel, podle nichž je nutné vědu modelovat jako dynamický systém nikoli jako formálně-logický stroj, kterýžto přístup nacházíme $\mathrm{v}$ dílech racionalistů i empiristů. $Z$ konceptu vědeckých revolucí analogicky odvozují na transformaci vědy prostřednictvím bifurkací, skrze něž věda získává novou dynamiku, nové vlastnosti, mění se vědecké experimenty, metody, teorie. Důsledkem těchto přechodů dochází k jistému porušení symetrie a v souvislosti s tím upozorňuje P. W. Anderson na nebezpečí redukcionistického přístupu ve vědě. Důvodem je vznik emergentních jevů při strukturaci komplexních systémů, mezi které věda bezpochyby náleží.

Komplexita systému je podmíněna jeho nevratností a nelinearita. Jestliže tyto principy aplikujeme na vědu, znamená to, že vědci spolu interagují v nelineárních vztazích a jsou začleněni do nevratných toků látky, energie a informací. Analytický přístup $\mathrm{k}$ modelování vědy tyto interakce redukuje na několik málo logických pravidel. $\mathrm{V}$ důsledku je tento př́ístup neadekvátní $\mathrm{k}$ dynamickému charakteru vědy, $\mathrm{v}$ níž se interakční pravidla mění v jednotlivých kontextech.

Současným trendem ve vědě je posun směrem $\mathrm{k}$ týmové spolupráci, který nastal v oblasti přírodních, sociálních a humanitních věd, inženýrství a umění přibližně od šedesátých let 20. století jako reakce na vzrůstající komplexitu vědeckých poznatků. Výsledky týmových výzkumů mají jednak větší vliv ve vědecké komunitě a také větší citační index. Tím se proměňuje struktura a dynamika vědecké evoluce. Vědečtí

\footnotetext{
${ }^{46}$ van Raan, A. F. J. Fractal Dimension of Co-citations. Nature, 347(626), 1990, s. 626.
} 
výzkumníci a vědecké články se navzájem podporují. Vědci prostřednictvím referencí propojují články v kocitační sítě a články spojují vědce ve koautorských sítích.

Na zakladatele scientometrie de Sola Price a jeho model citačních referencí navazuje van Raan, který dochází $\mathrm{k}$ závěru, že počet citovaných dokumentů je závislý na růstu a tedy stárnutí vědy a také na celkové produkci vědeckých prací. Rozvijí model růstu a diferenciace vědy ve třech následujících krocích. Za prvé, každý komplexní systém, je tvořen interagujícími subsystémy s vlastním exponenciálním růstem. Za druhé, nově vnikající subsystémy jsou „kolébkou“ pro zárodečný vývoj nových objevů, $\mathrm{k}$ nimž dojde s pravděpodobností proporcionální $\mathrm{k}$ velikosti daného subsystému. Za třetí, všechny subsystémy jsou distribuované na základě své velikosti.

$\mathrm{V}$ důsledku je tedy věda sebe-organizační kognitivní ekosystém, jehož fraktální povaha umožňuje změřit míru rozmanitosti tohoto systému, tedy distribuci jednotlivých „druhů vědců” mezi větší a menší vědní disciplíny, subdisciplíny apod.

Van Raan nepovažuje větší vědecké objevy za esenciálně odlišné od menších vědeckých objevů. To staví jeho koncepci do rozporu s Kuhnovou teorií vědeckých revolucí. Širší analýzu tohoto problému ovšem nepředkládá. Nicméně dle Priceho se jedná pouze o alternativní analýzu kriticky zkoumající své možné př́nosy.

V dalším pohledu na modelování současné podoby vědy a vědecké praxe je stř̌edem zájmu van Raanova kocitační analýza. $V$ jejím základu leží principy kocitace článků a principy vzniku kocitační mapy, které společně formují vědu v termínech fraktální dimenze. To znamená, že vědecký informační prostor má fraktální povahu, která je odrazem dynamického procesu, při němž z již etablovaných vědeckých oborů emergují nové oblastí výzkumného zájmu. Je zde tedy zřejmá vazba na povahu př́rodních ekosystémů jako takových, $\mathrm{z}$ nichž van Raan při popisu vědy v termínech dynamického kognitivního ekosystému vychází.

Z předložené studie vyplývá jistá potřeba modelů a metod pro "týmovou vědu“, určitého konceptuálního rámce schopného směřovat a udržet analýzu současných problémů napřrič obory. Je důležité, aby fungovala jistá korespondence mezi sociální dynamikou vědeckých komunit a vývojem vědeckých disciplín. Pro studium těchto disciplín a určení stupně vzájemné provázanosti odborníků z jednotlivých oblastí a tedy reflexi dynamiky vědy slouží kocitační analýza jako hodnotný nástroj. 


\section{Bibliografie}

Anderson, P. W. More Is Different. Broken Symmetry and the Nature of the Hierarchical Structure of Science. Science, 177(4047), 1972, s. 393-396.

Aristoteles. Metafyzika. Praha: Nakl. Jana Laichtera, 1946.

Barabási, A.-L. - Albert, R. Emergence of Scaling in Random Networks. Science, 286(5439), 1999, s. 509-512.)

Barrow, J. D. The World Within the World. Oxford: Clarendon Press, 1988.

Bellis, Nicola de. Bibliometrics and Citation Analysis: From the Science Citation Index to Cybernetics. Plymouth: The Scarecrow Press, Inc., 2009.

Börner, K. - Maru, J. T. - Goldstone, R. L. The Simultaneous Evolution of Author and Paper Networks. PNAS, 101(1), 2004, s. 5266-5273.

Coveney P. - Highfield, R. Mezi chaosem a řádem. Hranice komplexity: hledání řádu v chaotickém světě. Praha: Mladá fronta, 2003.

Diacu, F. The Solution of the $n$-body Problem. The Mathematical Intelligencer, 18(3), 1996, s. 66-70.

Fajkus, B. Filosofie a metodologie vědy. Vývoj, současnost a perspektivy. Praha: Academia, 2005.

Frontier, S. Applications of Fractal Theory to Ecology. In: Legendre, P. - Legendre, S. (eds.) Developments In Numerical Ecology. Springer Verlag: Berlin, 1987, s. 335 378.

Havemann, F. Einführung in die Bibliometrie. Berlin: Gesellschaft für Wissenschaftsforschung, 2009.

Herfel, W. E. - Hooker, C. A. From Formal Machine to Social Colony: Toward a Complex Dynamical Philosophy of Science. In: Dalla Chiara, M. L. - Giuntini, R. Laudisa, F. (eds.) Language, Quantum, Music: Select Proceedings of the 10th International Congress of Logic, Methodology and Philosophy of Science. Boston: Kluwer, 1999 , s. 7-18.

Hooker, C. A., ed. Handbook of the Philosophy of Science. Philosophy of Complex Systems. Amsterdam; London: North Holand (Elsevier), 2011. 
Hooker, C. A. Introduction to Philosophy of Complex Systems: A. In: Hooker, C. A. (ed.) Handbook of the Philosophy of Science. Philosophy of Complex Systems. Amsterdam; London: North Holand (Elsevier), 2011, s. 3-90.

Kuhn, T. S. Logic of Discovery or Psychology of Research? In: Lakatos, I. Musgrave, A. (eds.) Criticism and the Growth of Knowledge. London: Cambridge University Press, 1970, s. 1-23.

Kuhn, T. S. Reflections on my Critics. In: Lakatos, I. - Musgrave, A. (eds.) Criticism and the Growth of Knowledge. London: Cambridge University Press, 1970, s. 231-278.

Kuhn, T. S. Struktura vědeckých revolucí. Praha: OIKOYMENH, 1997.

MacRae, D, JR. Growth and Decay Curves in Scientific Citations. American Sociological Review, 34(5), 1969, s. 631-635.

Mandelbrot, B. How Long Is the Coast of Britain? Statistical Self-Similarity and Fractional Dimension. Science, 156(3775), 1967, s. 636-638.

Marshakova-Shaikevich, I. System of Document Connections Based on References. Nauchn-Techn. Inform., 6(2), 1973, s. 3-8.

Martins, B. Class CoCitation [online], [cit. 7. 6. 2014]. Dostupné z: http://webla.sourceforge.net/javadocs/pt/tumba/links/CoCitation.html).

Merton, R. K. The Sociology of Science. Chicago: University of Chicago Press, 1973.

Price, D. J. de Solla. Networks of Scientific Papers. Science, 149(3683), 1965, s. 510515.

Price, D. J. de Solla. Science Since Babylon. New Haven: Yale University Press, 1975.

Price, D. J. de Solla. A General Theory of Bibliometric and Other Cumulative Advantage Processes. Journal of The American Society for Information Science, 27(5), 1976, s. 292-306.

Richerson, P. J. - Boyd, R. Not by Genes Alone. How Culture Transformed Human Evolution. Chicago: UP, 2005.

Scheffler, I. Science and Subjectivity. Indianapolis: Hackett Publishing Company, 1982.

Small, H. Co-citation in The Scientific Literature: a New Measure of The Relationship Between Two Documents. Journal of the American Society for Information Science, 24(4), 1973, 265-269. 
Tebes, J. K. - Thai, N. D. - Matlin, S. L. Twenty-First Century Science as a Relational Process: From Eureka! To Team Science and a Place for Community Psychology. American Journal of Community Psychology, 53(3-4), 2014, s. 475-490.

van Raan, A. F. J. On growth and Fractal Diferentiation of Science. Scientometrics, 47(2), 2000, s. 347-362.

van Raan, A. F. J. Fractal Dimension of Co-citations. Nature, 347(626), 1990, s. 626.

Wuchty, S. - Jones, B. F. - Uzzi, B. The Increasing Dominance of Teams in Production of Knowledge. Science, 316(5827), 2007, s. 1036-1039. 


\section{E-LOGOS}

ELECTRONIC JOURNAL FOR PHILOSOPHY

Ročník/Year: 2014 (vychází průběžně/ published continuously)

Místo vydání/Place of edition: Praha

ISSN 1211-0442

Vydává/Publisher:

Vysoká škola ekonomická v Praze / University of Economics, Prague

nám. W. Churchilla 4

Czech Republic

13067 Praha 3

IČ: 61384399

Web: http://e-logos.vse.cz

Redakce a technické informace/Editorial staff and technical information:

Miroslav Vacura

vacuram@vse.cz

Redakční rada/Board of editors:

Ladislav Benyovszky (FHS UK Praha, Czech Republic)

Ivan Blecha (FF UP Olomouc, Czech Republic)

Martin Hemelík (VŠP Jihlava, Czech Republic)

Angelo Marocco (Pontifical Athenaeum Regina Apostolorum, Rome, Italy)

Jozef Kelemen (FPF SU Opava, Czech Republic)

Daniel Kroupa (ZU Plzeň, Czech Republic)

Vladimír Kvasnička (FIIT STU Bratislava, Slovak Republic)

Jaroslav Novotný (FHS UK Praha, Czech Republic)

Jakub Novotný (VŠP Jihlava, Czech Republic)

Ján Pavlík (editor-in-chief) (VŠE Praha, Czech Republic)

Karel Pstružina (VŠE Praha, Czech Republic)

Miroslav Vacura (executive editor) (VŠEE Praha, Czech Republic) 